\title{
Biotransformation of disperse dyes using nitroreductase immobilized on magnetic particles modified with tosyl group: Identification of products by LC-MS-MS and theoretical studies conducted with DNA ${ }^{\text {is }}$
}

\author{
Jefferson Honorio Franco a, ${ }^{\text {, }}$, Bianca F. da Silva a , Alexandre A. de Castro ${ }^{\text {b, }}$ \\ Teodorico C. Ramalho ${ }^{b}$, María Isabel Pividori ${ }^{c}$, Maria Valnice Boldrin Zanoni ${ }^{a}$ \\ a Institute of Chemistry - São Paulo State University “Julio de Mesquita Filho"-UNESP-Avenida Professor Francisco Degni, 55, Quitandinha, CEP: 14800-900, \\ Araraquara, SP, Brazil \\ b Department of Chemistry, Federal University of Lavras, 37200-000, Lavras, Brazil \\ ${ }^{\text {c } G r o u p ~ o f ~ S e n s o r s ~ a n d ~ B i o s e n s o r s, ~ A u t o n o m o u s ~ U n i v e r s i t y ~ o f ~ B a r c e l o n a, ~ B a r c e l o n a, ~ S p a i n ~}$
}

\section{A R T I C L E I N F O}

\section{Article history:}

Received 23 March 2018

Received in revised form 25 June 2018

Accepted 13 July 2018

Available online 17 July 2018

\section{Keywords:}

Biotransformation

Nitroreductase

Enzyme immobilized onto magnetite

Disperse dyes degradation

\begin{abstract}
A B S T R A C T
The present work evaluates the action of nitroreductase enzyme immobilized on Tosylactivated magnetic particles (MP-Tosyl) on three disperse dyes which contain nitro and azo groups. The dyes included Disperse Red 73 (DR 73), Disperse Red 78 (DR 78), and Disperse Red 167 (DR 167). The use of a magnet enabled the rapid and easy removal of the immobilized enzyme after biotransformation; this facilitated the identification of the products generated using high-performance liquid chromatography with diode array detector (HPLC-DAD) and mass spectrometry (LC-MS/MS). The main products formed by the in vitro biotransformation were identified as the product of nitro group reduction to the correspondent amine groups, which were denoted as follows: $50 \%$ of 2-(2-(4-((2-cyanoethyl)(ethyl)amino)phenyl)hydrazinyl)5-nitrobenzonitrile, $98 \%$ of 3-((4-((4-amino-2-chlorophenyl) diazenyl)phenyl) (ethyl)amino)propanenitrile and $99 \%$ of (3-acetamido-4 - ((4-amino-2-chlorophenyl) diazenyl) phenyl) azanediyl) bis (ethane2,1-diyl) for DR 73, DR 78 and DR 167, respectively. Based on the docking studies, the dyes investigated were found to be biotransformed by nitroreductase enzyme due to their favorable interaction with the active site of the enzyme. Theoretical results show that DR73 dye exhibits a relatively lower rate of degradation; this is attributed to the cyanide substituent which affects the electron density of the azo group. The docking studies also indicate that all the dyes presented significant reactivity towards DNA. However, Disperse Red 73 was found to exhibit a substantially higher reactivity compared to the other dyes; this implies that the dye possesses a relatively higher mutagenic power. The docking results also show that DR 73, DR 78 and DR 167 may be harmful to both humans and the environment, since the mutagenicity of nitro compounds is associated with the products formed during the reduction of nitro groups. These products can interact with biomolecules, including DNA, causing toxic and mutagenic effects.
\end{abstract}

๑) 2018 Elsevier Ltd. All rights reserved.

\section{Introduction}

Disperse dyes are colored, non-ionic aromatic compounds that commonly contain azo and nitro groups, and are widely used for dyeing synthetic fibers. There have been increasingly growing concerns regarding the environmental impacts of the use of these

\footnotetext{
This paper has been recommended for acceptance by B. Nowack.

* Corresponding author.

E-mail address: jeffersonhfranco@gmail.com (J.H. Franco).
}

dyes. These concerns largely stem from the fact that at the end of the dyeing process, the non-adsorbed dyes are discharged into industrial effluents after treatment. A poorly inadequate treatment system may potentially increase the presence of hazardous dye residues in wastewater, particularly, from textile processing plants. Among the dye residues include those from disperse dyes, which are regarded scarcely soluble in water (Carneiro et al., 2010a,b). The involuntary ingestion of these dyes may pose serious threats to the environment apart from causing considerable damages to human health. As recently described by numerous studies published in the 
literature, the dangers posed by various compounds of this class of disperse dyes need not be overemphasized. The harmful effects of these dyes are associated with their mutagenic properties which have been detected in a diverse range of assays (Chequer et al., 2011; Oliveira et al., 2010; Ferraz et al., 2011; Carneiro et al., 2010a,b).

The literature (de Aragão Umbuzeiro et al., 2005) has shown that the pattern of mutagenicity observed in selected disperse dyes (disperse blue 373, disperse violet 3 and disperse orange 37) can be attributed to the effects of the $\mathrm{NO}_{2}$ groups present in the chemical structures of these compounds. Their mutagenic response is potentialized when they are treated with YG 1041 (HisD3052, rfa, Dbio, DuvrB, pKM101) strain, which is a nitroreductase and Oacetyltransferase overproducer (Hagiwara et al., 1993). The same pattern of behavior can be noted in the use of Salmonella strain TA 98 (Maron and Ames, 1983).

Disperse Red 73 (DR 73), Disperse Red 78 (DR 78), and Disperse Red 167 (DR 167) are synthetic organic dyes, which are widely used in textile industries; their chemical structure is shown in Fig. 1. The dyes that bear azo groups are chromophore, and are characterized by very low solubility in water. The presence of $\mathrm{CN}$ - and $\mathrm{Cl}$ substituents in ortho position relative to nitro groups in the molecule interferes in the mutagenicity of these compounds (Franco et al., 2018). Salmonella/microsome assay (Franco et al., 2018) conducted on the TA 98 and TA 100 strains with and without liver microsomal fractions (S9) (Zbaida and Levine, 1990) indicated that DR 73 exhibited the highest mutagenicity among the dyes. In addition, the presence of S9 contributed towards an increase in mutagenic activity of DR 73. The interaction and reactivity of these compounds with DNA have also been evaluated by theoretical calculations; the results of these calculations indicated that DR 73, DR 78, and DR 167 may be hazardous to both human beings and the environment. The reason being that their biotransformation can produce harmful compounds, such as amines, which have been categorically disapproved by the International Agency for Research on Cancer (Franco et al., 2018; Brown and De Vito, 1993; Chung and Cerniglia, 1992).

Reports in the literature show that the toxicity of nitro aromatic compounds may be associated with the products formed during the reduction of nitro groups. Hydroxylamine derivatives can interact with biomolecules, including DNA, giving rise to toxic and mutagenic effects. The toxic effects are related to the electrophilic character of these derivatives, while the mutagenic effects are mainly associated with the formation of hydroxylamine moiety adducts through esterification with guanine (Corbett and Corbett, 1995).

The study of the biotransformation of nitroaromatic compounds via the use of nitroreductases is essentially interesting, in that it

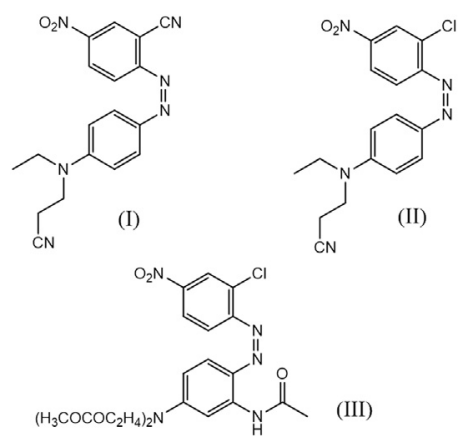

Fig. 1. Structure of Disperse Red 73 (DR 73) (I), Disperse Red 78 (DR 78) (II) and Disperse Red 167 (DR 167) (III) dyes. helps one to understand the change in the molecules promoted by the action of the enzyme, considering that nitroaromatic compounds can be potential environmental pollutants (Padda et al., 2003). Disperse dyes containing nitro and azo sites have been found to pose serious risks to human health, affecting the central nervous systems, heart, liver, and may eventually lead to death (Singh and Walker, 2006). Nitroreductases are a group of enzymes from intestinal bacteria and liver which play the central role of reducing aromatic nitro compounds in primary amine aromatic compounds (Bryant et al., 1981; Ling et al., 1992).

Among the advantages of enzymatic immobilization include the continuous use or reuse of enzymes, as well as the ease of recovery and low rate of product contamination (Cao, 2005; Grazú et al., 2005). Enzymatic immobilization can increase the resistance to thermal denaturation, in addition to contributing towards significant improvement of the enzymatic activity and its preservation for long periods (Krajewska, 2004; Tischer and Wedekind, 1999; Cao, 2005). In this context, the present study was aimed at the immobilization of nitroreductase on magnetic particles as a way of improving the reutilization potential of this enzyme (Bahar and Çelebi, 2000).

Since the early reports on magnetic separation technology (Rembaum et al., 1982), magnetic particles (MPs) have been used for preconcentration of a huge range of targets in a variety of applications. They can be easily modified with proteins for the magnetic separation and preconcentration of different target from complex specimens (Carinelli et al., 2015; Brandão et al., 2015). Furthermore, MPs can be easily incorporated on magnetoelectrodes for electrochemical readout using permanent magnets in near contact (Zacco et al., 2006). The integration of magnetic particles (MPs) provides additional advantages, since the use of MPs greatly improves the performance of the biological reaction by increasing the surface area, improving the washing steps and, importantly, minimizing the matrix effect. Moreover, MPs allow reduction of reaction times and reagent volumes. In addition, MPs can be easily magneto-actuated using permanent magnets (Carinelli et al., 2015). A wide range of enzymes have already been immobilized on magnetic nanoparticles, including cellulase (Khoshnevisan et al., 2011), lipase (Ren et al., 2011; Jiang et al., 2009), alcohol dehydrogenase (Liao and Chen, 2001). Yet, to date, no study has been reported regarding the immobilization of nitroreductase.

Based on the results obtained with the Ames Test by Franco et al., it is extremely important to study the metabolites formed by the reduction of the nitro and azo groups.

Thus, the present work investigates the biotransformation of disperse dyes containing nitro and azo groups (Disperse Red 73, Disperse Red 78, and Disperse Red 167) by the action of enzymes present in the intestinal microflora, such as nitroreductase, which was immobilized on $\mathrm{Fe}_{2} \mathrm{O}_{3}$ magnetic particles modified with the tosyl group.

The dyes and their biotransformation products were evaluated by liquid chromatography coupled to diode array detectors (HPLCDAD) and mass spectrometry (LC-MS/MS). This study seeks to validate previous work that indicates that the nitroreduction of nitro aromatic compounds can lead to the formation of more hazardous compounds than the original compounds. Studies on the interaction and reactivity of these compounds with DNA were also carried out using theoretical calculations aiming at highlighting the effect of change in the chemical structure as a result of the reduction of the nitro group through the action of the nitroreductase enzyme. These three dyes were selected for study because of their chemical similarity with only few different ligands. Therefore, we were interested in knowing if azo compounds with similar chemical structures but with few different ligands $\left(\mathrm{CN}^{-}\right.$and $\left.\mathrm{Cl}^{-}\right)$could 
provide more or less toxic metabolites after biotransformation process.

\section{Experimental}

\subsection{Materials and reagents}

Disperse Red 73 (DR 73), Disperse Red 78 (DR 78), and Disperse Red 167 (DR 167) were obtained from Classic Dyestuffs Inc. (High Point, NC, USA). The $\mathrm{Fe}_{2} \mathrm{O}_{3}$ magnetic particles modified with the tosyl group is assigned as Dynabeads ${ }^{\circledR} \mathrm{M}-280$ Tosylactivated and was acquired from Thermo Fisher Scientific company. The reagents used for the immobilization of nitroreductase included the following: $0.01 \mathrm{M}$ of borate buffer ( $\mathrm{pH} 8.5$ ), $3 \mathrm{M}$ of ammonium sulfate in borate buffer, phosphate buffered saline (PBS) with $0.1 \%$ bovine serum albumin (BSA) (pH 7.4), PBS with 0.5\% BSA (pH 7.4) and nitroreductase derived from Escherichia coli (purity of $90 \%$ by SDS-PAGE, recombinant units/mg protein $\geq 100$ ) were acquired from Sigma-Aldrich (Barcelona, CT, ESP). The reduced form of $\beta$ nicotinamide adenine dinucleotide phosphate (NADPH) was purchased from Sigma-Aldrich (Barcelona, CT, ESP). The chromatographic eluents included acetonitrile (ACN), supplied by Sigma Aldrich, and water purified in a MilliQ System (Millipore).

\subsection{Nitroreductase immobilization}

The nitroreductase immobilization is based on a covalent attachment of amine groups of the basic amino acid moieties present in the enzyme. The Scheme of the immobilization procedure is provided in Supp. data (Scheme S1).

The best experimental conditions obtained for the immobilization of nitroreductase enzyme are described as follows: $1 \mathrm{~mL}$ of $0.01 \mathrm{M}$ borate buffer ( $\mathrm{pH} 8.5$ ) and $35 \mu \mathrm{L}$ of tosylactivated magnetic particles (MP-Tosyl) added to an Eppendorf tube containing $100 \mu \mathrm{g}$ of nitroreductase $\left(2 \mathrm{mg} \mathrm{mL}^{-1}\right)$. Subsequently, $100 \mu \mathrm{L}$ of $3 \mathrm{M}$ ammonium sulfate buffer were added to the solution and mixed for $18 \mathrm{~h}$ at $700 \mathrm{rpm}$ in a turbmixer. Following homogenization by vortex and magnetic separation until a clear solution was obtained, the supernatant was removed and the particles were subjected to additional washing. Thereafter, the immobilized enzyme on MPTosyl was placed into $1 \mathrm{~mL}$ of PBS $0.5 \%$ BSA buffer (pH 7.4) and mixed at $37^{\circ} \mathrm{C}$ for $2 \mathrm{~h}$ at $700 \mathrm{rpm}$ so as to block the remaining active sites. The particles were washed twice with $1 \mathrm{~mL}$ of PBS $0.1 \%$ BSA buffer and were subsequently resuspended in $198 \mu \mathrm{L}$ of PBS $0.1 \%$ BSA (Dyal et al., 2003; Johnson et al., 2011) prior to being used in all the experiments.

\subsection{Determination of binding efficiency}

The Bradford's reagent was prepared by dissolving $10 \mathrm{mg}$ of Coomassie Brilliant Blue G 250 dye (Merck) in a solution with $5 \mathrm{~mL}$ of $95 \%$ ethanol (Merck) and $10 \mathrm{~mL}$ of phosphoric acid (Merck). The solution was vacuum filtered and the filtrate was placed in a $100 \mathrm{~mL}$ volumetric flask; the volume was filled with distilled water. The reaction between Coomassie dye and nitroreductase $(2.5 \mathrm{~mL})$ was performed in a polystyrene (disposable) cuvette, under agitation and at room temperature. After $10 \mathrm{~min}$ reaction, the solution was subjected to spectrophotometric UV/Vis analysis. The absorbance measurements were performed using a UV-Vis spectrophotometer at wavelength of $595 \mathrm{~nm}$. The amount of protein in the supernatant was determined by colorimetric method ( $595 \mathrm{~nm}$ ) using a Bio-Rad Protein Assay: Bradford (1976) concentrate using bovine serum albumin as the protein standard. The number of bound enzymes was calculated based on Eq. (1):
$\%$ of immobilized enzyme $=\mathrm{Ci}-\frac{\mathrm{Cs}}{\mathrm{Ci}} \times 100$

where $\mathrm{Ci}$ and $\mathrm{Cs}$ are the concentrations of nitroreductase initially used for reaction and the unbound nitroreductase, respectively.

The standard curve was prepared by plotting the average Blankcorrected measurements for each BSA standard $v s$ its concentration in $\mu \mathrm{g} \mathrm{mL}^{-1}$. The standard curve was used to determine the protein concentration of each sample; which is in this case, the concentration of immobilized nitroreductase on the magnetic particles. The absorbance values $(585 \mathrm{~nm}$ ) refer to the unbound enzyme. The solution turns blue due to the reaction of the enzyme with Coomassie Blue.

\subsection{Nitroreductase activity assay}

The activity of nitroreductase was determined spectrophotometrically at $37^{\circ} \mathrm{C}$ based on the procedure described by Bryant et al. (Bryant and DeLuca, 1991) with slight modifications. The oxidation of NADH at $340 \mathrm{~nm}$ using $\varepsilon 340 \mathrm{~nm}$ of $6.220 \mathrm{~L} \mathrm{~mol}^{-1} \mathrm{~cm}^{-1}$ was monitored by UV/vis spectrophotometer Hewlett Packard (HP) model 8453 in the range of $200-800 \mathrm{~nm}$ using thermostatic quartz cells of $1 \mathrm{~cm}$ path length.

The reaction mixture of $3 \mathrm{~mL}$ contained $0.1 \mathrm{M}$ sodium phosphate buffer ( $\mathrm{pH}$ 7.4), $1 \mathrm{mM}$ NADH and $0.2 \mathrm{mM}$ ortho-nitrophenol (ONP) substrate as well as $100 \mu \mathrm{L}$ of enzyme solution. One unit of enzyme activity was defined as the amount of enzyme required to reduce $1 \mathrm{mM}$ of ONP per min. Enzymatic activity was determined through the quantification of NADH formation, as measured by the increase in absorbance at $340 \mathrm{~nm}$. The absorbance values were recorded during $5 \mathrm{~min}$ of reaction (with an interval of $2 \mathrm{~s}$ between each measurement), and the initial velocity was calculated by linear regression during the first $2-3 \mathrm{~min}$ of reaction. The assays were conducted in triplicate, and controls without added enzyme were included in each experiment. One enzyme unit $(U)$ was defined as the amount of enzyme that hydrolyzes $1.0 \mathrm{~mol}$ of substrate per minute at $25^{\circ} \mathrm{C}$.

\subsection{Biotransformation of the selected textile dyes}

$20 \mu \mathrm{L}$ of each textile dye dissolved in acetonitrile (100 ppm) were placed in $50 \mu \mathrm{L}$ of nitroreductase enzyme immobilized on magnetic particles $\left(2 \mathrm{mg} \mathrm{mL}^{-1}\right)$ containing $20 \mu \mathrm{L} \quad \mathrm{NADPH}$ (10 $\mathrm{mg} \mathrm{mL}^{-1}$ ) and $310 \mu \mathrm{L}$ phosphate buffer ( $\mathrm{pH} 7.0$ ) in a final volume of $400 \mu \mathrm{L}$. The solutions were heated at $90^{\circ} \mathrm{C}$ and stirred at $700 \mathrm{rpm}$ for $60 \mathrm{~min}$ (Dai et al., 2009). Subsequently, the solution in the eppendorf tube was treated with external magnetic bar and the clear supernatant was collected for subsequent analysis.

\subsection{Analysis procedure}

The spectrophotometric measurements were carried out using Hewlett Packard (HP) spectrophotometer model 8453 in the range of $200-800 \mathrm{~nm}$. The solutions were placed in a $5-\mathrm{mL}$ quartz cuvette (Hellma) with optical path of $1.0 \mathrm{~cm}$.

An ultra-Turrax homogenizer, a Centrifuge Excelsa Baby model I 206, a Vortex IKA and ultracentrifuge Hitachi HIMAC CP90WX were used to perform the analysis.

HPLC analysis was carried out using a liquid chromatograph (Shimadzu, model LC-10AT) equipped with two pumps and an automatic injector (injection volume of $20 \mu \mathrm{L}$ ) coupled to a diode array detector (model SPD-M10AVP). The chromatograms were investigated in the range of $200-800 \mathrm{~nm}$; the maximum wavelengths selected for analysis of the DR 73, DR 78, and DR 167 dyes 
were 509,483 , and $510 \mathrm{~nm}$, respectively.

The HPLC analysis was performed with the aid of a reversedphase column (Shimadzu CLC-ODS, C18, $250 \mathrm{~mm} \times 4.6 \mathrm{~mm} \times$ $5 \mu \mathrm{m}, 100 \mathrm{~A}$ ) preceded by a pre-column (Luna Phenomenex, C18, $1 \mathrm{~cm} \times 4.6 \mathrm{~mm} \times 5 \mu \mathrm{m}, 100 \mathrm{~A}$ ). Prior to analysis, all the solutions were filtered through a $0.45-\mu \mathrm{m}$ PTFE filter. The best experimental conditions under the optimized isocratic mode were: mobile phase $=\mathrm{ACN} / \mathrm{H}_{2} \mathrm{O} 80: 20(\mathrm{v} / \mathrm{v})$, flow rate $=1.0 \mathrm{~mL} \mathrm{~min}^{-1}$, and column temperature $=30^{\circ} \mathrm{C}$. The analysis time was $10 \mathrm{~min}$. All the analyses were carried out in triplicate. UV-Vis spectra in the hydrodynamic mode were also recorded for each peak of the chromatograms.

The analysis by LC-MS/MS was conducted using liquid chromatography coupled to mass spectrometry (LC-MS/MS) in a 1200 Agilent Technologies HPLC coupled to a 3200 QTRAP mass spectrometer (Linear Ion Trap Quadrupole LC/MS/MS Mass Spectrometer), AB SCIEX Instruments, operating in the positive mode with Turbolon Spray ionization.

The chromatographic analyses were performed using a reversed-phase analytical column Luna C-18 (2) (measuring $250 \times 4.6 \mathrm{~mm}$ id, $5.0 \mu \mathrm{m})$. The mobile phase was $\mathrm{ACN} / \mathrm{H}_{2} \mathrm{O}$ mixture of $80: 20(\mathrm{v} / \mathrm{v})$ containing $0.1 \%$ formic acid at a flow rate of $1 \mathrm{~mL} \mathrm{~min}^{-1}$ in the isocratic mode. The injection volume and the column temperature were $10 \mu \mathrm{L}$ and $25^{\circ} \mathrm{C}$, respectively. The analyses lasted $10 \mathrm{~min}$.

Mass spectrometry (3200 QTRAP) was conducted with the full scan experiment in the enhanced mode (EMS, enhanced mass scan with the linear ion trap analyzer). Ionization was carried out using the Turbolon Spray source (electrospray) operating in the positive mode. Fragment ion experiments (EPI, enhanced product, also using the linear ion trap ion) were conducted aiming at obtaining structural information about the possible products.

\subsection{Computational details}

\subsubsection{Docking procedure}

To conduct the docking studies, the dyes, namely, DR 73, DR 78 and DR 167 were used to perform the calculations. The partial charges of atoms present in the structures of the dyes were calculated using the Gaussian 09 software (J. Frisch et al., 2009). The dyes were docked inside the crystallographic structure of nitroreductase from Escherichia coli (PDB code $1 \mathrm{ICU}$; resolution $=1.8 \AA$ ) (Lovering et al., 2001), using the Molegro Virtual Docker program $\left(M_{V D}^{\circledR}\right.$ ) (Thomsen and Christensen, 2006)(Silva et al., 2016). To perform the calculations, a radius of $5 \AA$ was considered, where the residues were kept as flexible. Due to the nature of the docking procedures, the calculations were carried out yielding 100 poses (conformation and orientation) for the ligands.

The MolDock scoring function employed in the MVD program comes from the piecewise linear potential (PLP), a simplified potential whose parameters are fitted to protein-ligand structures, binding data scoring functions and further extended in Generic Evolutionary Method for molecular docking with a new hydrogen bonding term and new charge schemes (Ramalho et al., 2009). EPLP stands for "piecewise linear potential", which consists of using two different parameter sets described as follows: one for approximation of the steric term (Van der Waals) among atoms, and the other potential for hydrogen binding (Thomsen and Christensen, 2006).

\subsubsection{Semi-empirical and quantum calculations}

Semi-empirical calculations are performed aiming at reducing the computational cost with a good level of accuracy. Currently, these methods, which have become widely popular, allow one to apply a quantum chemical treatment to big systems, such as biomolecules. The semi-empirical methods emerged in 1931 with the studies conducted by Michael Polanyl and Henry Eyring (Morgon and Coutinho, 2007), which shed light on quantum theory coupled to empirical results, giving rise to significant data. This category of methods enables one to deal with large systems with many atoms (Morgon and Coutinho, 2007). In this way, one is able to work with proteins, DNA, enzymes and other molecular systems. The PM6 semi-empirical method seems to be appropriate when it comes to performing calculations related to dyes and their metabolites in the crystallographic structure of B-DNA DODECAMER (binding energies) (Lercher et al., 2014).

To perform the calculations, the DICKERSON-DREW B-DNA DODECAMER was obtained from the Protein Data Bank (PDB) with code 4C64 and resolution $1.32 \AA$ (Lercher et al., 2014). This DNA structure was chosen as the model based on previously reported studies (Haris et al., 2015; Issar et al., 2015). The dyes and their metabolites were entirely optimized at DFT level for the subsequent PM6 semi-empirical affinity calculations with B-DNA. After that, the reaction mechanism simulation was carried out through the application of the QM/MM techniques (Franco et al., 2018). This methodology has exhibited significantly good performance in the treatment of large systems with high level of theory. The QM part was carried out at DFT level, with B3LYP functional density and 631G (d, p) basis set (de Castro et al., 2016; Sartorelli et al., 2016).

\section{Results and discussion}

\subsection{Binding efficiency and stability of enzymatic activity}

First, the MP-Tosyl control (without enzyme) was analyzed in order to evaluate the magnetic efficiency. Thus, with the aid of a magnet, the particles were completely separated from the solution, proving that they were in excellent condition for the enzyme analyzes.

With the aid of spectrophotometric measurements, the percentage of nitroreductase bound on MP-Tosyl was estimated as 91.4\%. The binding efficiency was calculated based on Eq. (1). The amount of total enzymes obtained via the Bradford method was $0.0764 \mathrm{mg} \mathrm{mL}^{-1}$. The enzymatic activity of the enzyme immobilized on MP-Tosyl was $55.3 \mu \mathrm{mol} \mathrm{min}{ }^{-1} \mathrm{mg}^{-1}$, while the enzymatic activity of the free enzyme was $66.3 \mu \mathrm{mol} \mathrm{min}{ }^{-1} \mathrm{mg}^{-1}$. The activity of the immobilized enzyme was $11 \%$ less than that of the free enzyme.

Remarkably, the most significant advantage of our studies with immobilized enzyme lies in their long-term stability. We noted constant activity over one month during our study of nitroredutase immobilized. The hybrid enzyme-magnetic particle composites showed only $\sim 15 \%$ decrease in activity after $30 \mathrm{~d}$. These experiments were carried out by separating the magnetic particles from the solution at the end of each day, and washing them with buffer solution. The recovery efficiency of the enzyme immobilized and free enzyme was above $97.5 \%$ during the $30 \mathrm{~d}$ of analysis. This result confirms that there was no loss of material during recovery, but a decrease in the enzymatic activity values. The data related to the stability of the enzymatic activity of both the free and immobilized nitroreductase enzymes over $30 \mathrm{~d}$ are presented in Table 1 . These results indicate that the immobilized nitroreductase suffered a loss of 15\% in enzymatic activity in $30 \mathrm{~d}$, whereas the free enzyme exhibited a loss of $54 \%$ of enzymatic activity during the same period.

Essentially, the long-term stability illustrates the advantage of attaching the enzymes chemically to the magnetic particles, making the use of expensive enzymes economically viable, which, thus, unfolds a new horizon for enzymatic catalysis in biotechnology (Johnson et al., 2008). Furthermore, the removal of enzyme from the solution facilitates the identification of the product generated, which is subjected to analysis by chromatographic techniques, including HPLC-DAD and LC-MS-MS. 
Table 1

Comparison of enzymatic activity of immobilized and free nitroreductase enzymes after 30 days.

\begin{tabular}{|c|c|c|}
\hline & Enzymatic activity of immobilized nitroreductase $\left(\mu \mathrm{mol} \mathrm{min}{ }^{-1} \mathrm{mg}^{-1}\right)$ & Enzymatic activity of free nitroreductase $\left(\mu \mathrm{mol} \mathrm{min}{ }^{-1} \mathrm{mg}^{-1}\right)$ \\
\hline First day & 55.3 & 66.3 \\
\hline After 5 days & 54,9 & 59.4 \\
\hline After 10 days & 54.2 & 51.0 \\
\hline After 15 days & 53.1 & 44.7 \\
\hline After 20 days & 50.8 & 39.2 \\
\hline After 25 days & 48.3 & 34.6 \\
\hline After 30 days & 47.0 & 30.3 \\
\hline
\end{tabular}

\subsection{HPLC-DAD analysis}

Fig. $2(A-C)$ shows the HPLC-DAD chromatograms obtained for $20 \mathrm{mg} \mathrm{L}^{-1}$ of DR 73 (A), DR 78 (B), and DR 167 (C) before (Curve 1) and after (Curve 2) the action of immobilized nitroreductase enzyme under the following optimized conditions: column $\mathrm{C} 18$, mobile phase $=\mathrm{ACN} / \mathrm{H}_{2} \mathrm{O} 80: 20(\mathrm{v} / \mathrm{v})$, flow rate $=1.0 \mathrm{~mL} \mathrm{~min}^{-1}$, and $\mathrm{T}=30^{\circ} \mathrm{C}$. In the same figure, one will observe the results of the comparison involving the UV-Vis spectra obtained in the hydrodynamic mode for the dyes before (Curve 1) and after (Curve 2) enzymatic degradation. Well-defined single chromatographic peaks (peak 1) were obtained for DR 73, DR 78 and DR 167 dyes before the enzymatic reaction (Curve 1 ) at retention times of 4.42 ; 6.36 and $5.95 \mathrm{~min}$, respectively. The respective UV/Vis spectra obtained at hydrodynamic conditions are also shown in the insert of Fig. 2. The UV/Vis spectra of each dye presented defined spectra with bands of maxima absorbance at 512, 485 and $529 \mathrm{~nm}$, for DR 73, DR 78 and DR 167 dyes, respectively, at Curve 1 in Fig. 2A, B and
2C. These bands are attributed to the azo group present as chromophore in all the dyes investigated. Following the biotransformation with nitroreductase enzyme (Curve 2), one notices a reduction in the dye peak area of up to $50 \%, 98 \%$ and $99 \%$ for DR 73 , DR 78 and DR 167 dyes, respectively. These results indicate that while DR 78 and DR 167 were found to be almost completely degraded after 60 min of treatment, DR 73 dye experienced a much lower degradation rate. On the other hand, the chromatographs show the occurrence of new peaks at $t_{r}=2.13$ min (peak 2) and $t_{r}=3.90$ min (peak 2) for DR 78 and DR 167 dyes, respectively. Another observation that deserves mentioning is the appearance of two chromatographic peaks which are associated with the DR 73 dye after the enzymatic reaction at the retention times of 2.22 (peak 3) and 3.50 (peak 2) min. Following the biotransformation with nitroreductase enzyme (Curve 2), one notices a reduction in the dye peak area of up to $50 \%, 98 \%$ and $99 \%$ for DR 73 , DR 78 and DR 167 dyes, respectively. These results indicate that while DR 78 and DR 167 were found to be almost completely degraded after 60 min
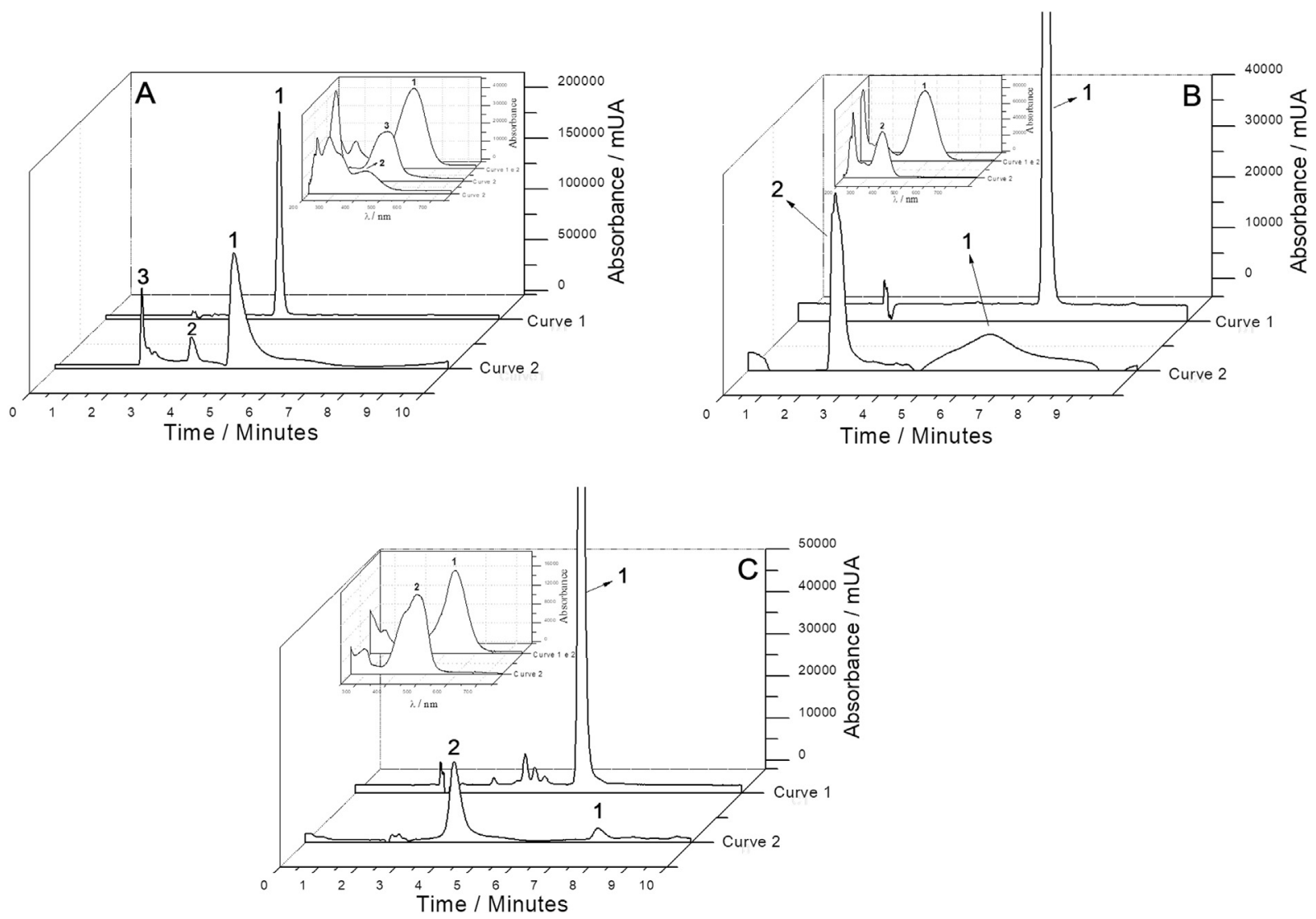

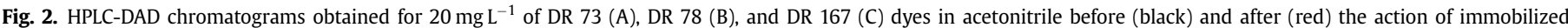

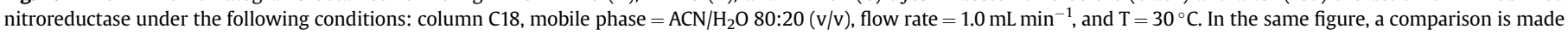
regarding the UV-Vis spectra obtained in the hydrodynamic mode for the dyes before (black) and after (red) enzymatic degradation. 
of treatment, DR 73 dye experienced a much lower degradation rate. This behavior demonstrates the formation of new subproducts during the biotransformation reaction. The subproducts were subjected to analysis by mass spectrometry aiming at determining the reduction site of the molecule.

\subsection{LC-MS/MS analysis}

The LC-MS/MS chromatographic profile obtained for DR 73, DR 78 and DR 167 standard dyes $\left(20 \mu \mathrm{g} \mathrm{mL}^{-1}\right)$ in EMS mode showed the elution of DR 73 dye at $4.62 \mathrm{~min}$ with $\mathrm{m} / \mathrm{z} 349$, which corresponded to the protonated molecule, $[\mathrm{M}+\mathrm{H}]^{+}$(Fig. S1a) and its fragmentation pattern (Fig. S1b). DR 78 dye was detected at 6.76 min, with $\mathrm{m} / \mathrm{z} 359\left([\mathrm{M}+\mathrm{H}]^{+}\right.$) (Fig. S2a, fragmentation pattern S2b), while DR 167 dye was detected at $6.20 \mathrm{~min}$, with $\mathrm{m} / z 506$ $\left([\mathrm{M}+\mathrm{H}]^{+}\right.$(Fig. S3a, fragmentation pattern S3b).

The potential metabolite (1) of DR 73 obtained after 60 min of treatment with nitroreductase enzyme is detected through the mass spectra of $m / z 319\left([\mathrm{M}+\mathrm{H}]^{+}\right)$at $3.49 \mathrm{~min}$, which is attributed to the product of nitro group reduction of DR 73 to $-\mathrm{NH}_{2}$ substituent. This product was further confirmed through the analysis of extracted ion chromatogram and fragment ions (EPI) of $m / z 319$ (Fig. S4(A-B)). In addition, the peak of the fragment ion mass spectrum with $m / z 278$ is found to be the base peak corresponding to the methyl cyanide loss (41 Da). Another fragment ion that was observed was $m / z 222$, this is suggestive of the loss of the disubstituted amine, which was bound to the aromatic ring, as shown in Scheme 1. Thus, the main enzymatic reduction of DR 73 lies in the conversion of nitro group towards the formation of the amine group assigned as: 2-(2-(4-((2-cyanoethyl)(ethyl)amino)phenyl) hydrazinyl)-5-nitrobenzonitrile. The chemical structure is shown in Table 2.

The biotransformation of DR 78 dye by the nitroredutase enzyme exhibited a peak with $\mathrm{m} / \mathrm{z} 328\left([\mathrm{M}+\mathrm{H}]^{+}\right)$at $3.83 \mathrm{~min}$ (Fig. S5(A)); the mass difference of 30 Da relative to the molecular ion may indicate a chemical reduction in the nitro group, $\left(-\mathrm{NO}_{2}\right)$ to $\mathrm{NH}_{2}$. The potential product was further confirmed through the analysis of fragment ions (EPI) of $m / z 328$ (Fig. S5(B), $m / z 287$ and $m /$ $z 259$ corresponding, respectively, to the loss of a methyl cyanide (41 Da), loss of one ethyl group and cleavage of the amine bond linked to the azo group, which is connected to the chlorinated aromatic ring (Scheme 2). Thus, the main product derived (2) from the reduction of DR 78 via the action of nitroredutase is the 3-((4((4-amino-2-chlorophenyl)diazenyl)phenyl)(ethyl)amino)propanenitrile, as shown in Table 2.

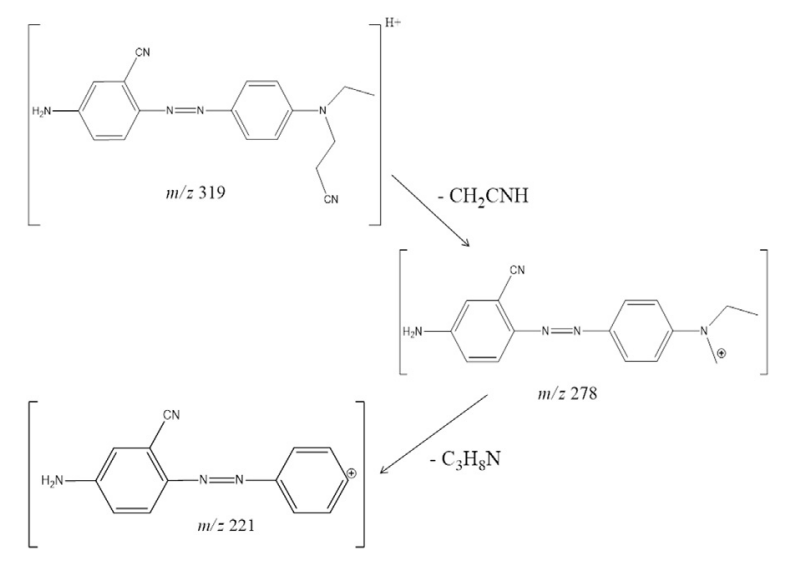

Scheme 1. Fragmentation proposal for the metabolite (1) $m / z 319$, formed after incubation of $20 \mu \mathrm{g} \mathrm{mL}^{-1}$ of standard DR 73 dye with immobilized nitroreductase enzyme.
The biotransformation of DR 167 dye following the enzymatic reaction showed a single peak at $3.67 \mathrm{~min}$ with $\mathrm{m} / z 476\left([\mathrm{M}+\mathrm{H}]^{+}\right)$ (Fig. S6(A)); this indicates the reduction of the nitro group to $-\mathrm{NH}_{2}$. The presence of this potential metabolite (3) was confirmed by fragment ions $m / z 434$ (42 Da) and $m / z 416$ (60 Da) (Fig. S6(B)) related to the loss of acetaldehyde and acetic acid, respectively, as shown in Scheme 3. Thus, the main product derived from the reduction of DR 167 through the action of nitroreductase is (3acetamido-4 - ((4-amino-2-chlorophenyl) diazenyl) phenyl) azanediyl) bis (ethane-2,1-diyl) diacetate, as shown in Table 2.

The present results indicate that the biotransformation reaction with the immobilized nitroreductase enzyme for the DR 73, DR 78 and DR 167 dyes resulted in only one main metabolite for each dye, where $\mathrm{NO}_{2}$ group is converted to $\mathrm{NH}_{2}$ group. Our findings are slightly different from those of previous studies reported in the literature that indicated the formation of $\mathrm{N}$-hydroxylamines as the main product derived from the reduction of nitro groups. To verify whether these reductions from nitro groups to amine groups may induce DNA damage (Arlt, 2002 (Chadwick et al., 1992), and the difficulty encountered to get enough subproducts to conduct biological measurements, the products were studied through the application of theoretical calculations regarding the interactions of the original dyes and the products detected with DNA.

\subsection{Docking results}

The docking methodology aims to predict the ligand binding mode and ligand affinities within a target binding site. In this sense, one important aspect is the docking of small molecules into protein binding pockets (Huang and Zou, 2010). Docking programs are able to assess the best conformations of ligand in terms of energy and positioning, allowing the investigation of protein-ligand molecular interactions. The results are presented in Table S1.

The data in Table S1 reveal that all the dyes presented favorable interaction energies in the active site of nitroreductase. Based on the results presented here, all the dyes studied interact with the protein and are found to be capable of being biotransformed, resulting in the formation of metabolites, as discussed previously. It is worth noting that lower intermolecular interaction energy values lead to a better accommodation and affinity for the ligand in the active site of the enzyme. From our theoretical findings, Disperse Red 78 exhibited the best interaction energy in the active site of nitroreductase, with an energy value of about $-27.17 \mathrm{kcal} \mathrm{mol}^{-1}$, followed by Disperse Red $167\left(-26.71 \mathrm{kcal} \mathrm{mol}^{-1}\right)$ and Disperse Red $73\left(-21.33 \mathrm{kcal} \mathrm{mol}^{-1}\right)$, respectively. Now, when one takes into account the interactions of each dye in the active site, DR 73 was found to present the lowest interaction value with the enzyme, this interaction is modulated by only one amino acid residue (Ser40) and three water molecules. By contrast, DR 78 exhibited interactions with two amino acid residues - Arg207 and Lys20, and three water molecules. Interestingly, DR 167 presented the highest number of interactions, six amino acid residues (Arg207, Ser12, Lys14, Lys74, Ser40, Glu165) and three water molecules. These results are in agreement with the percentage of biotransformation of DR 73, DR 78 and DR 167 which reached 50\%, 98\% and 99\%, respectively, after 60 min of nitroreductase action.

With the aid of the docking calculations, one will observe that the DR 73, DR 78 and DR 167 dyes interacted very well with the nitroreductase enzyme and are likely to have undergone biotransformation, leading to the formation of their metabolites. One should note, however, that DR 73 exhibited the lowest values compared to both DR 78 and DR 167. These results indicate that the cyanide substituent acts as an electron-withdrawing agent, decreasing the reactivity of the azo group, which is more resistant to discoloration due to lower enzymatic interaction. 
Table 2

Biotransformation products of Disperse Red 73, Disperse Red 78 and Disperse Red 167 dyes after reaction with immobilized nitroreductase.

\begin{tabular}{|c|c|c|c|c|}
\hline Dyes & Metabolites & Structure & $\begin{array}{l}m / z \text { Retention time } \\
(\mathrm{min})\end{array}$ & Fragmentation \\
\hline Disperse Red 73 & $\begin{array}{l}\text { 2-(2-(4-((2-cyanoethyl)(ethyl)amino)phenyl)hydrazinyl)-5- } \\
\text { nitrobenzonitrile }\end{array}$ & & 3193,42 & 278,$3 ; 222,2$ \\
\hline Disperse Red 78 & $\begin{array}{l}\text { 3-((4-((4-amino-2-chlorophenyl)diazenyl)phenyl) } \\
\text { (ethyl)amino)propanenitrile }\end{array}$ & & 3283,78 & $\begin{array}{l}287,2 ; 259,2 ; \\
126,0\end{array}$ \\
\hline $\begin{array}{l}\text { Disperse Red } \\
\quad 167\end{array}$ & $\begin{array}{l}\text { (3-acetamido-4 - ((4-amino-2-chlorophenyl) diazenyl) phenyl) azanediyl) } \\
\text { bis } \\
\text { (ethane-2,1-diyl) diacetate }\end{array}$ & & 4763,66 & 434,$2 ; 416,2$ \\
\hline
\end{tabular}

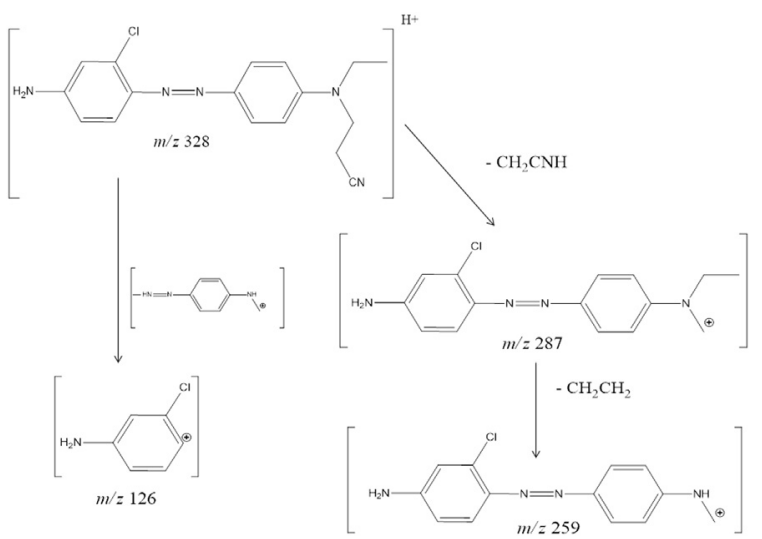

Scheme 2. Fragmentation proposal for the metabolite (2) $m / z 328$, formed after incubation of $20 \mu \mathrm{g} \mathrm{mL}^{-1}$ of standard DR 78 dye with immobilized nitroreductase enzyme.

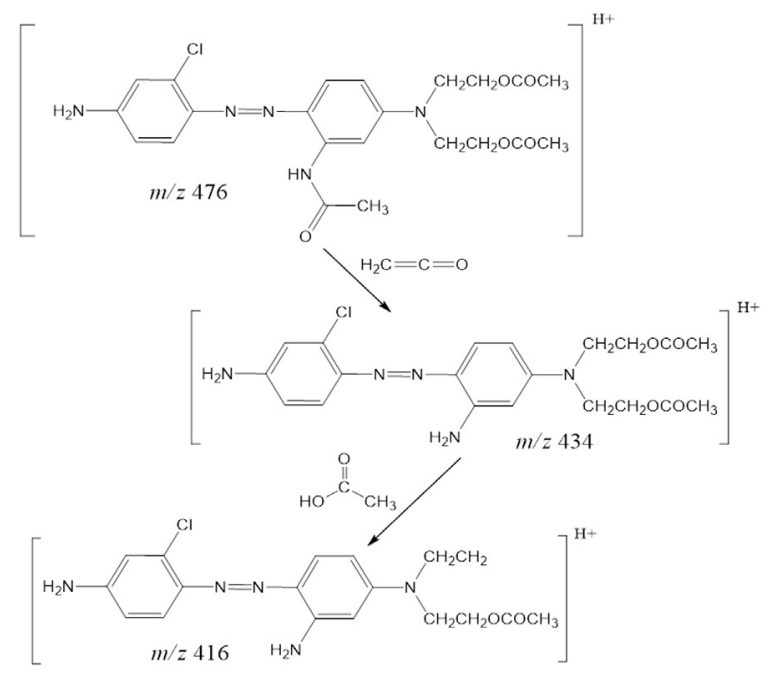

Scheme 3. Fragmentation proposal for the metabolite (3) $m / z 476$, formed after incubation of $20 \mu \mathrm{g} \mathrm{mL}^{-1}$ of standard DR 167 dye with immobilized nitroreductase enzyme.

\subsubsection{Relative interaction and activation energy of the metabolites} generated after treatment with nitroreductase

Based on the theoretical methodology employed in other works (Silva et al., 2016), PM6 semi-empirical calculations were applied in order to evaluate the interaction between each dye, including metabolites, with human DNA. This methodology has demonstrated its capability of simulating large systems, considering the presence of electronic effects. The theoretical findings are described in Table S2.

The dyes and their metabolites may be extremely toxic, inducing carcinogenic, mutagenic or teratogenic effects on diverse organisms, including human beings (Franco et al., 2018). The intoxication associated with these compounds may be related to biotransformation processes. The data in Table S2 show that Disperse Red 73 dye is the most mutagenic compound, followed by Disperse Red 167 (26.40 $\left.\mathrm{kcal} \mathrm{mol}^{-1}\right)$ and Disperse Red $78\left(37.19 \mathrm{kcal} \mathrm{mol}^{-1}\right)$. It is worth pointing out that these values are given in relation to DR 73 (relative energy values). The interaction of DR 73 with DNA may be related to the presence of the cyanide group, which strongly interacts with DNA, as can be observed in the optimized structures.

A further point that needs mentioning here is the theoretical study of the biotransformation products formed from each dye through the nitroreductase enzyme. According to the affinity data, the DR 73 metabolite, (2-(2-(4-((2-cyanoethyl) (ethyl)amino) phenyl) hydrazinyl)-5-nitrobenzonitrile), involving the reduction of nitro group to amine group, presented an energy value (24.45 $\mathrm{kcal} \mathrm{mol}^{-1}$ ) higher than that of the precursor dye. Hence, the calculations imply that DR 73 may be more carcinogenic than its metabolite. However, this observation is not applicable to the DR 78 and DR 167.

The metabolite derived from DR 78 dye, (3-((4-((4-amino-2chlorophenyl)diazenyl)phenyl)(ethyl)amino)propanenitrile, which involved the reduction of nitro group to amine group, presented a more stable interaction energy than the precursor dye, with an energy difference of about $24.83 \mathrm{kcal} \mathrm{mol}^{-1}$. The same can be observed for the metabolite from DR 167 (3-acetamido-4 - ((4amino-2-chlorophenyl) diazenyl) phenyl) azanediyl) bis (ethane2,1-diyl) diacetate, with a difference of $8.83 \mathrm{kcal} \mathrm{mol}^{-1}$. Quite different from the DR 73, these theoretical data indicate that the metabolites derived from DR 78 and DR 167 may be more carcinogenic than the precursor dye; this is reinforced by the better interaction of these biotransformation products with DNA. It is important to keep in mind, however, that all compounds studied here have significant potential to interact with DNA, causing mutations, for instance, via alkylation mechanisms (Luczak and Jagodzinski, 2006; Mitra et al., 2007).

As aforementioned, the DR 73 presented the best interaction with DNA, and as expected, it also seems to be more reactive, showing the lowest activation energy for the alkylation reaction mechanism pathway. The DR 78 presented the highest energetic 
barrier for the process, and its energy difference relative to DR 73 was about $5.13 \mathrm{kcal} \mathrm{mol}^{-1}$. DR 167 exhibited a median relative energy value $\left(2.69 \mathrm{kcal} \mathrm{mol}^{-1}\right)$. With regard to the metabolic compounds, our theoretical findings from the reaction mechanism show that the metabolite from DR 73 is relatively less reactive than the precursor dye. No such feature was noted for DR 78 and DR 167.

\section{Final considerations}

The results obtained in this study essentially confirm that the immobilization of nitroreductase enzyme on Tosylactivated magnetic particles (MP-Tosyl) is economical, facile and efficient. The enzyme can be easily recovered and reused for several times without evident loss of activity.

Based on the theoretical studies, the dyes investigated are found to be capable of being biotransformed by the nitroreductase enzyme due to their favorable interaction with the active site of the enzyme, as shown in the docking results. These findings lead us to the conclusion that all the dyes presented significant reactivity towards DNA. Remarkably, the Disperse Red 73 presented a substantially higher reactivity compared to the other dyes; this implies that it also possesses a relatively higher mutagenic power. The metabolites formed from each precursor dye formed a stable complex with DNA. The study also found that DR 73 is more reactive than its metabolite.

To sum up, the azo dyes, namely, DR 73, DR 78 and DR 167, can be metabolized by gastrointestinal tract enzyme, such as nitroreductase, leading to the formation of possible mutagenic compounds. One will note that this is possible insofar as the reduction steps used in this work are considered to be mimicking endogenous reactions. Having seen the negative effects associated with the exposure to these dyes, it seems reasonable to say that extreme caution should be exercised when it comes to their use and application, particularly in the textile industries. Considering that the dye residues find their way into wastewater, effective treatments of these effluents and drinking water must be rigorously enforced so as to avoid environmental and human contact with these compounds. It is clear that an oral exposure to these compounds will lead to the ingestion of possible mutagenic products that may pose serious risks to both human health and the environment.

\section{Acknowledgements}

The authors are grateful for the financial support granted by CNPq (200309/2015-3 and 400459/2012-4), CAPES, FAPEMIG and FAPESP (2008/10449-7 and 2015/18109-4).

\section{Appendix A. Supplementary data}

Supplementary data related to this article can be found at https://doi.org/10.1016/j.envpol.2018.07.054.

\section{References}

Arlt, V.M., 2002. Metabolic activation of the environmental contaminant 3nitrobenzanthrone by human acetyltransferases and sulfotransferase. Carcinogenesis 23, 1937-1945. https://doi.org/10.1093/carcin/23.11.1937.

Bahar, T., Celebi, S.S., 2000. Performance of immobilized glucoamylase in a magnetically stabilized fluidized bed reactor (MSFBR). Enzym. Microb. Technol. 26, 28-33. https://doi.org/10.1016/S0141-0229(99)00129-5.

Bradford, M.M., 1976. A rapid and sensitive method for the quantitation of microgram quantities of protein utilizing the principle of protein-dye binding. Anal. Biochem. 72, 248-254. https://doi.org/10.1016/0003-2697(76)90527-3.

Brandão, D., Liébana Girona, S., Pividori, I., 2015. Multiplexed detection of foodborne pathogens based on magnetic particles. N. Biotech. 32, 511-522. https://doi.org/ 10.1016/j.nbt.2015.03.011.

Brown, M.A., De Vito, S.C., 1993. Predicting azo dye toxicity. Crit. Rev. Environ. Sci. Technol. 23, 249-324. https://doi.org/10.1080/10643389309388453.
Bryant, C., DeLuca, M., 1991. Purification and characterization of an oxygeninsensitive $\mathrm{NAD}(\mathrm{P}) \mathrm{H}$ nitroreductase from Enterobacter cloacae. J. Biol. Chem. 266, 4119-4125.

Bryant, D.W., McCalla, D.R., Leeksma, M., Laneuville, P., 1981. Type I nitroreductase of Escherichia coli. Can. J. Microbiol. 27, 81-86. https://doi.org/10.1139/m81 013.

Cao, L., 2005. Immobilised enzymes: science or art? Curr. Opin. Chem. Biol. 9, 217-226. https://doi.org/10.1016/j.cbpa.2005.02.014.

Carinelli, S., Martí, M., Alegret, S., Pividori, I., 2015. Biomarker detection of global infectious diseases based on magnetic particles. N. Biotechnol. https://doi.org/ 10.1016/j.nbt.2015.04.002.

Carneiro, P.A., Oliveira, D.P., Umbuzeiro, G.A., Zanoni, M.V.B., 2010a. Mutagenic activity removal of selected disperse dye by photoeletrocatalytic treatment J. Appl. Electrochem. 40, 485-492. https://doi.org/10.1007/s10800-009-0018-9.

Carneiro, P.A., Umbuzeiro, G.A., Oliveira, D.P., Zanoni, M.V.B., 2010b. Assessment of water contamination caused by a mutagenic textile effluent/dyehouse effluen bearing disperse dyes. J. Hazard Mater. 174, 694-699. https://doi.org/10.1016/ j.jhazmat.2009.09.106.

Chadwick, R.W., Elizabeth George, S., Claxton, L.D., 1992. Role of the gastrointestinal mucosa and microflora in the bioactivation of dietary and environmental mutagens or carcinogens. Drug Metab. Rev. 24, 425-492. https://doi.org/10.3109/ 03602539208996302.

Chequer, F.M.D., Lizier, T.M., de Felicio, R., Zanoni, M.V.B., Debonsi, H.M., Lopes, N.P., Marcos, R., de Oliveira, D.P., 2011. Analyses of the genotoxic and mutagenic potential of the products formed after the biotransformation of the azo dye Disperse Red 1. Toxicol. Vitro 25, 2054-2063. https://doi.org/10.1016/ j.tiv.2011.05.033.

Chung, K.-T., Cerniglia, C.E., 1992. Mutagenicity of azo dyes: structure-activity relationships. Mutat. Res. Genet. Toxicol. 277, 201-220. https://doi.org/10.1016 0165-1110(92)90044-A.

Corbett, M.D., Corbett, B.R., 1995. Bioorganic chemistry of the arylhydroxylamine and nitrosoarene functional groups. In: Spain, J.C. (Ed.), Biodegradation of Nitroaromatic Compounds. Springer US, Boston, MA, pp. 151-182. https:// doi.org/10.1007/978-1-4757-9447-2 10.

Dai, R., Chen, J., Lin, J., Xiao, S., Chen, S., Deng, Y., 2009. Reduction of nitro phenols using nitroreductase from E. coli in the presence of NADH. J. Hazard Mater. 170 141-143. https://doi.org/10.1016/j.jhazmat.2009.04.122.

de Aragão Umbuzeiro, G., Freeman, H.S., Warren, S.H., de Oliveira, D.P., Terao, Y, Watanabe, T., Claxton, L.D., 2005. The contribution of azo dyes to the mutagenic activity of the Cristais River. Chemosphere 60, 55-64. https://doi.org/10.1016/ j.chemosphere.2004.11.100.

de Castro, A.A., Caetano, M.S., Silva, T.C., Mancini, D.T., Rocha, E.P., da Cunha, E.F.F., Ramalho, T.C., 2016. Molecular docking, metal substitution and hydrolysis reaction of chiral substrates of phosphotriesterase. Comb. Chem. High Throughput Screen. 19, 334-344. https://doi.org/10.2174/ 1386207319666160325113844.

Dyal, A., Loos, K., Noto, M., Chang, S.W., Spagnoli, C., Shafi, K.V.P.M., Ulman, A. Cowman, M., Gross, R.A., 2003. Activity of Candida rugosa lipase immobilized on $\gamma$-Fe2O3 magnetic nanoparticles. J. Am. Chem. Soc. 125, 1684-1685. https:// doi.org/10.1021/ja021223n.

Ferraz, E.R.A., Umbuzeiro, G.A., De-Almeida, G., Caloto-Oliveira, A., Chequer, F.M.D. Zanoni, M.V.B., Dorta, D.J., Oliveira, D.P., 2011. Differential toxicity of Disperse Red 1 and Disperse Red 13 in the Ames test, HepG2 cytotoxicity assay, and Daphnia acute toxicity test. Environ. Toxicol. 26, 489-497. https://doi.org/ $10.1002 /$ tox.20576.

Franco, J.H., Silva, B.F. da, Oliveira, R.V., Meireles, G., de Oliveira, D.P., Castro, A.A. de Ramalho, T.C., Zanoni, M.V.B., 2018. Identification of biotransformation products of disperse dyes with rat liver microsomes by LC-MS/MS and theoretical studies with DNA: structure-mutagenicity relationship using Salmonella/microsome assay. Sci. Total Environ. 613-614, 1093-1103. https://doi.org/10.1016 j.scitotenv.2017.08.271.

Frisch, M.J., Trucks, G.W., Schlegel, H.B., Scuseria, G.E., Robb, M.A., Cheeseman, J.R. Scalmani, G., Barone, V., Mennucci, B., Petersson, G.A., Nakatsuji, H., Caricato, M. Li, X., Hratchian, H.P., Izmaylov, A.F., Bloino, J., Zheng, G., Sonnenberg, J.L., Hada, M., Fox, D.J., 2009. Gaussian 09 (Revision A02). Gaussian Inc., Wallingford CT.

Grazú, V., Abian, O., Mateo, C., Batista-Viera, F., Fernández-Lafuente, R., Guisán, J.M. 2005. Stabilization of enzymes by multipoint immobilization of thiolated proteins on new epoxy-thiol supports. Biotechnol. Bioeng. 90, 597-605. https:// doi.org/10.1002/bit.20452.

Hagiwara, Y., Watanabe, M., Oda, Y., Sofuni, T., Nohmi, T., 1993. Specificity and sensitivity of Salmonella typhimurium YG1041 and YG1042 strains possesing elevated levels of both nitroreductase and acetyltransferase activity. Mutat. Res. Mutagen. Relat. Subj. 291, 171-180. https://doi.org/10.1016/0165-1161(93) 90157-U.

Haris, P., Mary, V., Haridas, M., Sudarsanakumar, C., 2015. Energetics, thermodynamics, and molecular recognition of piperine with DNA. J. Chem. Inf. Model. 55, 2644-2656. https://doi.org/10.1021/acs.jcim.5b00514.

Huang, S.-Y., Zou, X., 2010. Advances and challenges in protein-ligand docking. Int. J. Mol. Sci. 11, 3016-3034. https://doi.org/10.3390/ijms11083016.

Issar, U., Kumari, T., Kakkar, R., 2015. Assessment of molecular binding of Hoechst 33258 analogues into DNA using docking and MM/GBSA approach. J. Comput. Sci. 10, 166-177. https://doi.org/10.1016/j.jocs.2015.05.003.

Jiang, Y., Guo, C., Xia, H., Mahmood, I., Liu, C., Liu, H., 2009. Magnetic nanoparticles supported ionic liquids for lipase immobilization: enzyme activity in catalyzing 
esterification. J. Mol. Catal. B Enzym. 58, 103-109. https://doi.org/10.1016/ j.molcatb.2008.12.001.

Johnson, A.K., Zawadzka, A.M., Deobald, L.A., Crawford, R.L., Paszczynski, A.J., 2008 Novel method for immobilization of enzymes to magnetic nanoparticles. J. Nanoparticle Res. 10, 1009-1025. https://doi.org/10.1007/s11051-007-9332-5.

Johnson, P.A., Park, H.J., Driscoll, A.J., 2011. Enzyme nanoparticle fabrication: magnetic nanoparticle synthesis and enzyme immobilization. In: Methods in Molecular Biology (Clifton, N.J.). United States, pp. 183-191. https://doi.org/ 10.1007/978-1-60761-895-9 15.

Khoshnevisan, K., Bordbar, A.-K., Zare, D., Davoodi, D., Noruzi, M., Barkhi, M. Tabatabaei, M., 2011. Immobilization of cellulase enzyme on superparamagnetic nanoparticles and determination of its activity and stability. Chem. Eng. J. 171, 669-673. https://doi.org/10.1016/j.cej.2011.04.039.

Krajewska, B., 2004. Application of chitin- and chitosan-based materials for enzyme immobilizations: a review. Enzym. Microb. Technol. 35, 126-139. https:// doi.org/10.1016/j.enzmictec.2003.12.013.

Lercher, L., McDonough, M.A., El-Sagheer, A.H., Thalhammer, A., Kriaucionis, S, Brown, T., Schofield, C.J., 2014. Structural insights into how 5hydroxymethylation influences transcription factor binding. Chem. Commun. 50, 1794-1796. https://doi.org/10.1039/c3cc48151d.

Liao, M.-H., Chen, D.-H., 2001. Immobilization of yeast alcohol dehydrogenase on magnetic nanoparticles for improving its stability. Biotechnol. Lett. 23, 1723-1727. https://doi.org/10.1023/A:1012485221802.

Ling, W.H., Hänninen, O., Mykkänen, H., Heikura, M., Salminen, S., Von Wright, A., 1992. Colonization and fecal enzyme activities after oral lactobacillus GG administration in elderly nursing home residents. Ann. Nutr. Metab. 36, 162-166. https://doi.org/10.1159/000177712.

Lovering, A.L., Hyde, E.I., Searle, P.F., White, S.A., 2001. The structure of Escherichia coli nitroreductase complexed with nicotinic acid: three crystal forms at $1.7 \mathrm{~A}$ $1.8 \mathrm{~A}$ and 2.4 A resolution. J. Mol. Biol. 309, 203-213. https://doi.org/10.1006 jmbi.2001.4653.

Luczak, M.W., Jagodzinski, P.P., 2006. The role of DNA methylation in cancer development. Folia Histochem. Cytobiol. 44, 143-154.

Maron, D.M., Ames, B.N., 1983. Revised methods for the Salmonella mutagenicity test. Mutat. Res. Mutagen. Relat. Subj 113, 173-215. https://doi.org/10.1016 0165-1161(83)90010-9.

Mitra, D., Kar, M., Pal, R., Basak, A., 2007. Synthesis and reactivity of azobenzenebased bispropargyl sulfones: interesting comparison between cyclic and acyclic systems. Bioorg. Med. Chem. Lett 17, 4514-4517. https://doi.org/10.1016/ j.bmcl.2007.06.001.

Morgon, N.H., Coutinho, K., 2007. Métodos de Química Teórica e Modelagem Molecular. Editora Livraria da Física, São Paulo.

Oliveira, G.A.R., Ferraz, E.R.A., Chequer, F.M.D., Grando, M.D., Angeli, J.P.F., Tsuboy, M.S., Marcarini, J.C., Mantovani, M.S., Osugi, M.E., Lizier, T.M. Zanoni, M.V.B., Oliveira, D.P., 2010. Chlorination treatment of aqueous samples reduces, but does not eliminate, the mutagenic effect of the azo dyes Disperse Red 1, Disperse Red 13 and Disperse Orange 1. Mutat. Res. Toxicol. Environ. Mutagen 703, 200-208. https://doi.org/10.1016/j.mrgentox.2010.09.001.

Padda, R.S., Wang, C., Hughes, J.B., Kutty, R., Bennett, G.N., 2003. Mutagenicity of nitroaromatic degradation compounds. Environ. Toxicol. Chem. 22, 2293. https://doi.org/10.1897/02-220.

Ramalho, T.C., Caetano, M.S., da Cunha, E.F.F., Souza, T.C.S., Rocha, M.V.J., 2009. Construction and assessment of reaction models of class I EPSP synthase: molecular docking and density functional theoretical calculations. J. Biomol. Struct. Dyn. 27, 195-207.

Rembaum, A., Yen, R.C.K., Kempner, D.H., Ugelstad, J., 1982. Cell labeling and magnetic separation by means of immunoreagents based on polyacrolein microspheres. J. Immunol. Meth. 52, 341-351. https://doi.org/10.1016/00221759(82)90006-0.

Ren, Y., Rivera, J.G., He, L., Kulkarni, H., Lee, D.-K., Messersmith, P.B., 2011. Facile, high efficiency immobilization of lipase enzyme on magnetic iron oxide nanoparticles via a biomimetic coating. BMC Biotechnol. 11, 63. https://doi.org/ 10.1186/1472-6750-11-63.

Sartorelli, J., de Castro, A.A., Ramalho, T.C., Giacoppo, J.O.S., Mancini, D.T. Caetano, M.S., da Cunha, E.F.F., 2016. Asymmetric biocatalysis of the nerve agent VX by human serum paraoxonase 1: molecular docking and reaction mechanism calculations. Med. Chem. Res. 25, 2521-2533. https://doi.org/10.1007/ s00044-016-1704-X.

Silva, M.C., Torres, J.A., Castro, A.A., da Cunha, E.F.F., Alves de Oliveira, L.C., Corrêa, A.D., Ramalho, T.C., 2016. Combined experimental and theoretical study on the removal of pollutant compounds by peroxidases: affinity and reactivity toward a bioremediation catalyst. J. Biomol. Struct. Dyn. 34, 1839-1848. https:// doi.org/10.1080/07391102.2015.1063456.

Singh, B.K., Walker, A., 2006. Microbial degradation of organophosphorus compounds. FEMS Microbiol. Rev. 30, 428-471. https://doi.org/10.1111/j.15746976.2006.00018.x.

Thomsen, R., Christensen, M.H., 2006. MolDock: a new technique for high-accuracy molecular docking. J. Med. Chem. 49, 3315-3321.

Tischer, W., Wedekind, F., 1999. Immobilized enzymes: methods and applications. In: Fessner, W.-D., Archelas, A., Demirjian, D.C., Furstoss, R., Griengl, H., Jaeger, K.-E., Morís-Varas, E., Öhrlein, R., Reetz, M.T., Reymond, J.-L., Schmidt, M., Servi, S., Shah, P.C., Tischer, W., Wedekind, F. (Eds.), Biocatalysis - from Discovery to Application. Springer Berlin Heidelberg, Berlin, Heidelberg, pp. 95-126. https://doi.org/10.1007/3-540-68116-7_4.

Zacco, E., Pividori, I., Alegret, S., Galve, R., Marco, M.-P., 2006. Electrochemical magnetoimmunosensing strategy for the detection of pesticides residues. Anal. Chem. 78, 1780-1788. https://doi.org/10.1021/ac0512610.

Zbaida, S., Levine, W.G., 1990. Characteristics of two classes of azo dye reductase activity associated with rat liver microsomal cytochrome P450. Biochem. Pharmacol. 40, 2415-2423. https://doi.org/10.1016/0006-2952(90)90081-U. 